\title{
Species Richness, Abundance and Functional Diversity of a Bat Community along an Elevational Gradient in the Espinhaço Mountain Range, Southeastern Brazil
}

Author(s): Eduardo De Rodrigues Coelho, Adriano Pereira Paglia, Arleu Barbosa Viana-Junior, Luiz A. Dolabela Falcão and Guilherme B. Ferreira Source: Acta Chiropterologica, 20(1):129-138.

Published By: Museum and Institute of Zoology, Polish Academy of Sciences

https://doi.org/10.3161/15081109ACC2018.20.1.009

URL: http://www.bioone.org/doi/full/10.3161/15081109ACC2018.20.1.009

BioOne (www.bioone.org) is a nonprofit, online aggregation of core research in the biological, ecological, and environmental sciences. BioOne provides a sustainable online platform for over 170 journals and books published by nonprofit societies, associations, museums, institutions, and presses.

Your use of this PDF, the BioOne Web site, and all posted and associated content indicates your acceptance of BioOne's Terms of Use, available at www.bioone.org/page/terms of use.

Usage of BioOne content is strictly limited to personal, educational, and non-commercial use. Commercial inquiries or rights and permissions requests should be directed to the individual publisher as copyright holder. 


\title{
Species richness, abundance and functional diversity of a bat community along an elevational gradient in the Espinhaço mountain range, southeastern Brazil
}

\author{
Eduardo de Rodrigues Coelho ${ }^{1,8}$, Adriano Pereira Paglia $^{2}$, Arleu Barbosa Viana-Junior ${ }^{3}$, \\ Luiz A. Dolabela Falcão ${ }^{4}$, and Guilherme B. Ferreira ${ }^{5,6,7}$ \\ ${ }^{1}$ Programa de Pós-Graduação em Biomas Tropicais, Universidade Federal de Ouro Preto, Ouro Preto, MG, Brazil \\ ${ }^{2}$ Laboratório de Ecologia e Conservação, Departamento de Biologia Geral, Universidade Federal de Minas Gerais, Av. \\ Presidente Antonio Carlos 6627, Pampulha, Belo Horizonte, MG, Brazil \\ ${ }^{3}$ Laboratório de Ecologia de Insetos, Departamento de Biologia Geral, Universidade Federal de Minas Gerais, \\ Belo Horizonte, $M G$, Brazil \\ ${ }^{4}$ Departamento de Biologia Geral, Universidade Estadual de Montes Claros - Unimontes, Montes Claros, MG, Brazil \\ ${ }^{5}$ Instituto Biotrópicos, Praça JK, 25, Diamantina, MG, Brazil \\ ${ }^{6}$ Centre for Biodiversity \& Environment Research, University College London, Gower Street, London, United Kingdom \\ ${ }^{7}$ Institute of Zoology, Zoological Society of London, Regent's Park, London, United Kingdom \\ ${ }^{8}$ Corresponding author:E-mail:durc2@yahoo.com.br
}

Bats are an excellent taxonomic group for research on elevational gradients and functional diversity, as they present a large number of species and functional traits. In general, elevation has a negative influence on bat diversity, but the effect is not necessarily linear. Often the effect of elevation on diversity may have a hump-shaped pattern, in which diversity metrics peak in intermediate elevations before decreasing at the highest parts of the elevational gradient. In this study, we investigated the effect of elevation on bat species richness, abundance, and functional diversity in Rio Preto State Park (RPSP), a protected area located in the Espinhaço mountain range, a region globally recognized for its high rates of biodiversity. We found that RPSP harbours 22 bat species, which represent $69 \%$ of the species occurring in the Espinhaço range and include species of conservation concern. Bat species richness and abundance was linearly and inversely correlated to elevation, whereas functional diversity had a hump-shaped pattern, with higher values found in the intermediate portion of the elevational gradient. Our findings agree with other studies showing the overall negative effect of elevation on bat diversity and contribute to the still sparse knowledge about the effect of elevation on bats in Brazil and in the Espinhaço range. Furthermore, our results suggest that natural environments in lower and intermediate elevations $(<1,100$ $\mathrm{m}$ a.s.l.) in this mountain range may have high biodiversity value for bats, and actions aiming at their protection would complement the conservation efforts focusing on endemic species associated with higher habitats in the Espinhaço.

Key words: Chiroptera, Cerrado, environmental gradient, mountain ecosystems

\section{INTRODUCTION}

Elevational gradients are important systems to investigate patterns of species richness and functional diversity, as they provide heterogeneous habitats and climatic conditions along short distances (Körner, 2000; Sanders and Rahbek, 2012). The variation in elevation influences the abundance and distribution of mammal species, but species may respond differently to this gradient (Dias and Peracchi, 2008). In this context, two patterns are often observed when assessing the effect of elevation on mammals. The first consists of a linear decrease in species richness and abundance with an increase in elevation (Stevens, 1992; Patterson et al., 1996, 1998; Kañuch and Kristin, 2006), usually observed in temperate climates (Graham, 1983; McCain, 2007b). The second pattern, defined by its hump-shaped effect, shows that in tropical regions intermediate elevations may have greater species richness and abundance (Rahbek, 1995, 2005; Goodman et al., 1996; Heaney, 2001; McCain, 2007b; Bordignon and França, 2009; Williams et al., 2012; Piksa et al., 2013).

Several studies have reported that elevation influences the local bat community (Juste and Perez, 1995; Patterson et al., 1998; Heaney, 2001; Jaberg and Guisan, 2001; Curran et al., 2012), and both 
patterns of elevational effect have been observed (hump-shaped and linear decrease). Heaney et al. (1989) in the Philippines, Linden et al. (2014) in South Africa, and Martins et al. (2015) in Brazil, found a linear and negative relationship between bat species richness and elevation, whereas greater species richness in intermediate elevations has been reported in Brazil, Colombia and Poland (Bejarano-B. et al., 2007; Stevens, 2013; and Piksa et al., 2013, respectively). McCain (2007b) found evidence of greater species richness in intermediate elevations when mountains have dry and arid bases, but in mountains with wet and warm bases the linear decrease pattern typically prevails.

The decrease in species richness along elevational gradients may result in decreased functional diversity and ecosystem services associated with bats (Dehling et al., 2014). Functional diversity is a biodiversity component representing the variation of species' features that influences community functioning (Tilman, 2001) and is an emerging property that explains the effects of biodiversity (Díaz et al., 2006). Analysis of functional diversity along environmental gradients is a complementary approach to traditional species richness studies and can help elucidate causes and consequences of general phenomena related to biodiversity variation (Stevens et al., 2003). Among vertebrates, bats are an excellent model group for research on functional diversity because they contribute to several ecosystem services (Kunz et al., 2011).

There are few studies in Brazil assessing bat diversity at different elevations (e.g., Geraldes, 1999; Esbérard, 2004; Dias and Peracchi, 2008; Moras et al., 2013; Martins et al., 2015), and even fewer of these incorporate functional diversity metrics. Furthermore, although some studies have investigated the effect of elevation on biodiversity in the Espinhaço range (e.g., Vasconcelos and Mello, 2001; Carneiro et al., 2005, 2009; Costa et al. 2015; Coutinho et al., 2015; Nunes et al., 2016; Pinho et al., 2017), there is very little information about its influence on bat communities in this mountain range. To start filling this gap in knowledge, we assessed the effect of elevation on bat species richness, abundance, and functional diversity at Rio Preto State Park, a protected area in the central portion of Espinhaço range. We tested the hypothesis that elevation has a hump-shaped effect on bat diversity, with metrics reaching their highest values in intermediate elevations and then decreasing at higher sampling sites.

\section{Materials AND Methods}

\section{Study Area}

The Espinhaço mountain range extends for about 1,200 km North to South, encompassing the Brazilian states of Minas Gerais and Bahia, with elevation varying between 650 and 2,000 $\mathrm{m}$ a.s.l. (Vitta, 2002). This mountain range is globally recognized for its high rates of endemism and for its rare and threatened species (Eterovick et al., 2005; Rodrigues, 2005; Rapini et al., 2008; Costa, et al., 2015; Silveira et al., 2015; Barata et al., 2016; Hopper et al., 2016).

This study was carried out at Rio Preto State Park (RPSP), located in the central portion of the Espinhaço range, at the border between two major Brazilian ecosystems - Cerrado and Atlantic Rainforest (Fig. 1). The park was established in 1994 in order to safeguard water sources and protect local biodiversity. RPSP covers an area of 12,185 hectares and has an elevational gradient of roughly $1,200 \mathrm{~m}$, with its lowest point at approximately $700 \mathrm{~m}$ a.s.1. and its highest point at $1,822 \mathrm{~m}$ a.s.1. Within RPSP limits, the main vegetation physiognomies are savanna (cerrado sensu stricto), grasslands with rock outcrops (campo rupestre), riparian forests, as well as scattered high-elevation forests (capão de mata). In general, the study area region has a seasonal climate with a dry season between April-September and a wet season between October-March; the average annual rainfall is $1,350 \mathrm{~mm}$ (IEF-MG, 2004). During our study the mean temperature at RPSP was $21.2^{\circ} \mathrm{C}$ (range: $4.3-38.3^{\circ} \mathrm{C}$; data from a weather station located at $850 \mathrm{~m}$ a.s.1. in the study area).

\section{Data collection}

We surveyed bats at 12 sampling sites within RPSP between August 2014 and September 2015, selecting sites as far apart as possible, while still fully representing the elevational gradient, as well as the protected area (Fig. 1). Selection of sampling sites was constrained by our sampling design (distance of at least three $\mathrm{km}$ among sites) and characteristics of the terrain, as cliffs and large rock outcrops made some portions of the study area virtually inaccessible. The shortest distance between two neighbouring sampling sites ranged from 3-4.5 km and the mean vertical distance between adjacent sampling sites was $91.8 \mathrm{~m}$ (range: $18-173 \mathrm{~m}$ ). The lowest sampling site (P1) was located at approximately $750 \mathrm{~m}$ a.s.1., while the highest (P12; ca. 1,760 m a.s.l.) was at the Dois Irmãos peak. Elevation was determined in the field, using a GPS unit (Garmin Map60CSx) and Kestrel 3500 Delta $\mathrm{T}$, both equipped with barometric altimeter.

To capture bats, we set $10(2.5 \times 12 \mathrm{~m}, 16 \mathrm{~mm}$ mesh $)$ at each sampling site in potential flight routes, such as natural open trails. Surveys started at 06:00 pm and finished at midnight, with the nets being inspected for animals every 30 minutes during this period. Bats were identified with the assistance of Gardner's identification key (2008) and standard biometric measures were taken [forearm measure, weight, sex, age (juvenile, adult), reproductive status (lactating, pregnant)]. Bats captured were also fitted with metal flanged bands and released at the same site. A small number of voucher specimens were collected and deposited in the Mammals Collection of ICB-UFMG (SISBIO permit 40471-1 and CEUA permit 135/2012). We conducted seven data collection expeditions, each one with 12 nights in length (one night per sampling site), totaling 84 sampling nights and a sampling effort of 5,040 net-hours (number of nets $\times$ number of nights $\times$ sampling hours per night). 
Since other factors can also influence the bat community, we measured two variables that we deemed to be important in our study area: weather and vegetation. We used the Kestrel 3500 Delta device to collect data on relative humidity, temperature, and wind speed. These measurements were made at the beginning and end of each sampling night; we used the average value of each night in the analysis. To account for variation in vegetation, we used the normalized difference vegetation index (NDVI), obtained from Landsat 8 satellite images taken approximately in the middle of our study period. NDVI is related to vegetation productivity (Pettorelli et al., 2005) and is well correlated to landscape green cover in the Brazilian Cerrado (Ferreira et al., 2003). NDVI values were calculated by averaging the values of each pixel of a $250 \mathrm{~m}$ buffer zone produced around each sampling site, using the software ArcGIS 10.

\section{Data analysis}

To estimate bat species richness in RPSP, we used the nonparametric richness estimator Jackknifel (Colwell and Coddington, 1994), one of the most effective tools to estimate this parameter (Palmer, 1990; Walther and Moore, 2005). Considering each night as a sampling occasion, we constructed species accumulation curves with 999 randomizations for observed and estimated species richness.

To obtain functional diversity metrics, we combined an abundance matrix with a trait matrix. Data on the following traits were extracted from the literature (Norberg and Rayner, 1987; Eisenberg and Redford, 1989; Gannon et al., 1989; Bianconi et al., 1996, 1998; Emmons and Feer, 1997; Norberg, 1998; Bernard and Fenton, 2003; Meyer et al., 2008; Reis, 2013) and used for all species: weight, feeding guild, aspect ratio (ratio between wing span and width) and type of shelter used (Supplementary Table S1). Rao's quadratic entropy is a measure of ecological community diversity (Rao, 1982) and is based on the proportion of the abundance of species present in a community and a measure of dissimilarity among them. The dissimilarity ranges from 0 to 1 and is based on a set of specified functional traits. For trait data, the function calculates the square root of the one-complement of Gower's similarity index, in order to obtain a dissimilarity matrix with Euclidean metric properties. Gower's index ranges from 0 to 1 and can handle traits measured at different scales (Botta-Dukát, 2005). When species are completely different in terms of their traits, Rao's quadratic entropy is equivalent to the Gini-Simpson index. Functional redundancy is defined simply as the difference between species diversity and Rao's quadratic entropy based on their functional dissimilarity (Bello et al., 2007), and can be

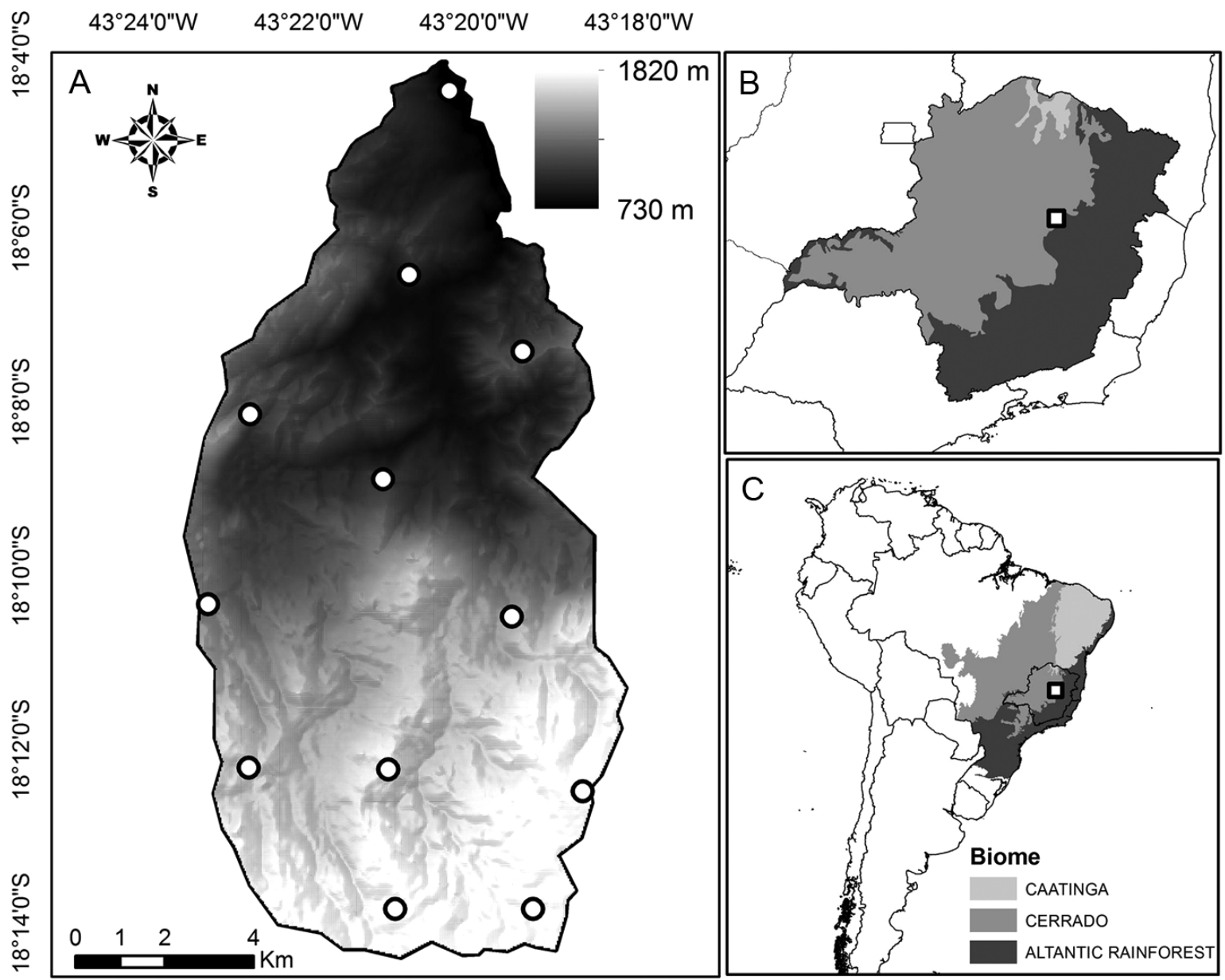

FIG. 1. Location of sampling sites (white circles) along the elevational gradient at Rio Preto State Park (A); and study area (white square) location in Minas Gerais state (B) and in South America (C) 
understood as the overlap of species' functional characteristics (traits) that affect ecosystem functioning (Loreau, 2004).

In order to test the effect of environmental variables on the bat community, we constructed generalized linear models (GLMs). We used observed species richness, abundance of bats (total number of individuals captured), Gini-Simpson diversity index, Rao's quadratic entropy and functional redundancy as response variables. For each response variable a multiple regression model was constructed adding all environmental factors together (explanatory variables) with no interactions: $y \sim$ NDVI + Wind Speed + Relative Humidity +Temperature + Elevation + Elevation $^{2}$. Checking for collinearity among elevation and the other explanatory variables, we found that it was only correlated to NDVI $(r=-0.70)$. However, we decided to keep NDVI in our full model because it could be useful to distinguish between sampling sites at similar elevation but with contrasting vegetation structure. All models followed Gaussian distribution errors and minimal adequate models were obtained by removing non-significant explanatory variables $(P>0.05)$ from the full model. Models were submitted to residual analyses (Supplementary Fig. S1), in order to assess adequacy of error distribution (Crawley, 2012). Before conducting our analysis, we performed the Moran's I test to check for spatial (horizontal distance) and elevational (vertical distance) autocorrelation among sampling sites. Results of the test indicated no evidence of autocorrela-tion for sampling sites close to each other, both horizontally $(P>0.05$; shortest distance: three $\mathrm{km})$ and vertically $(P>0.05$; smallest difference in elevation: $20 \mathrm{~m})$.

All analyses were performed in software R ver. 3.3.0 (R Core Team, 2016), using the package 'vegan' (Oksanen et al., 2016) to build species accumulation curves and the package SYNCSA (Debastiani and Pillar, 2012), using the function 'rao.diversity', to obtain metrics of functional diversity. For all analyses, we grouped species of the Lonchophylla genus as Lonchophylla spp. because three species of this genus potentially occur in our study area and identification to species level could not be achieved in the field for all individuals captured.

\section{RESULTS}

We captured 408 individuals, belonging to 22 species and three families of bats (Table 1). Estimated species richness at RPSP was 27 (Jackknife 1 estimator), five species greater than the observed value (Fig. 2). Observed species richness per sampling site ranged between five and 16 , while total abundance varied from 8 to 67 individual bats per site (Table 2). Lonchophylla spp. was the most frequently captured species representing $17 \%$ of all captures, followed by Glossophaga soricina (14\%), and Platyrrhynus lineatus (11\%). Conversely, Chiroderma doriae, Glyphonycteris behnii, Uroderma magnirostrum, Molossops temminckii, and Eumops perotis were captured only once and at elevations lower than 1,190 m a.s.1.; while Lonchophylla spp., Artibeus obscurus, P. lineatus were captured in 11 out of 12 sampling sites along the elevational gradient (Table 1 and Supplementary Fig. S2).

Elevation had a significant effect on species richness, abundance and functional diversity (Table 3, Fig. 3, and Supplementary Fig. S3), but not on GiniSimpson diversity index, which did not vary much and was relatively high throughout the study area (Table 2). There was a suggestion that elevation and NDVI might have some influence on functional redundancy, but the model for this metric did not converge adequately and we prefer not make any inferences. All other explanatory variables (wind speed, relative humidity and temperature) did not significantly affect any of the parameters assessed.

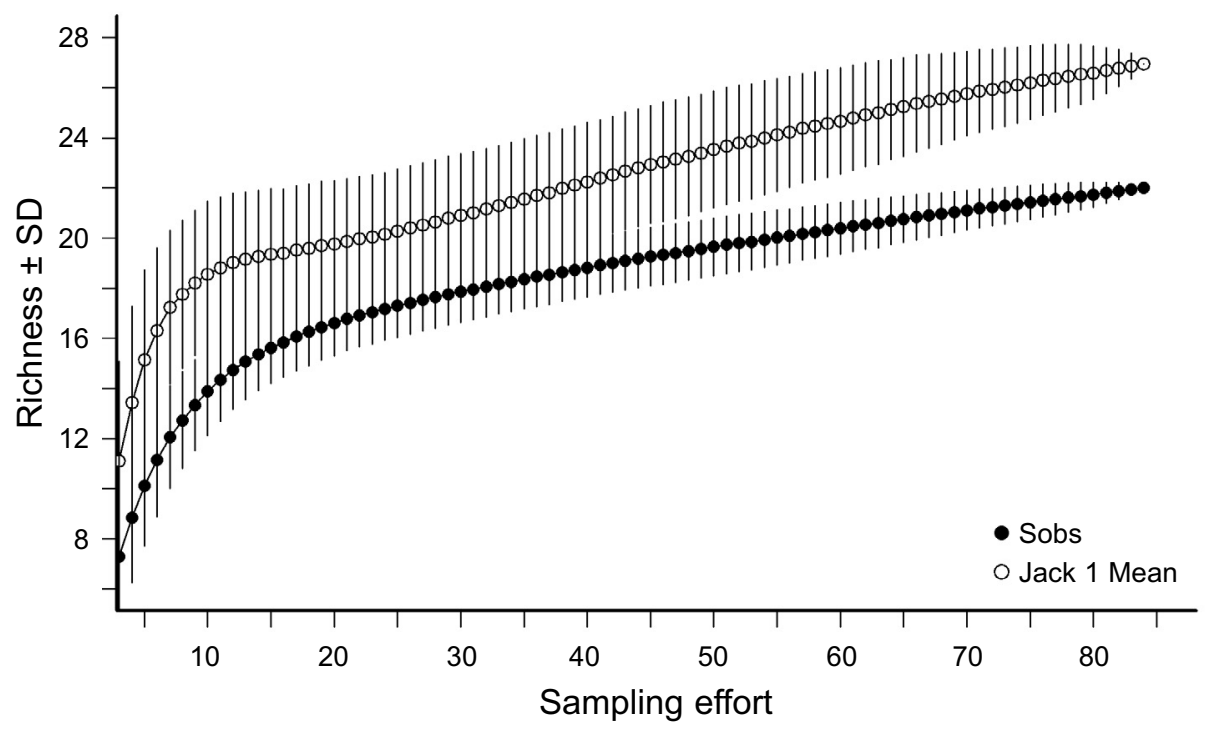

FIG. 2. Accumulation curves for observed (Sobs) and estimated (Jackknife 1 Mean) bat species richness at Rio Preto State Park, southeastern Brazil 


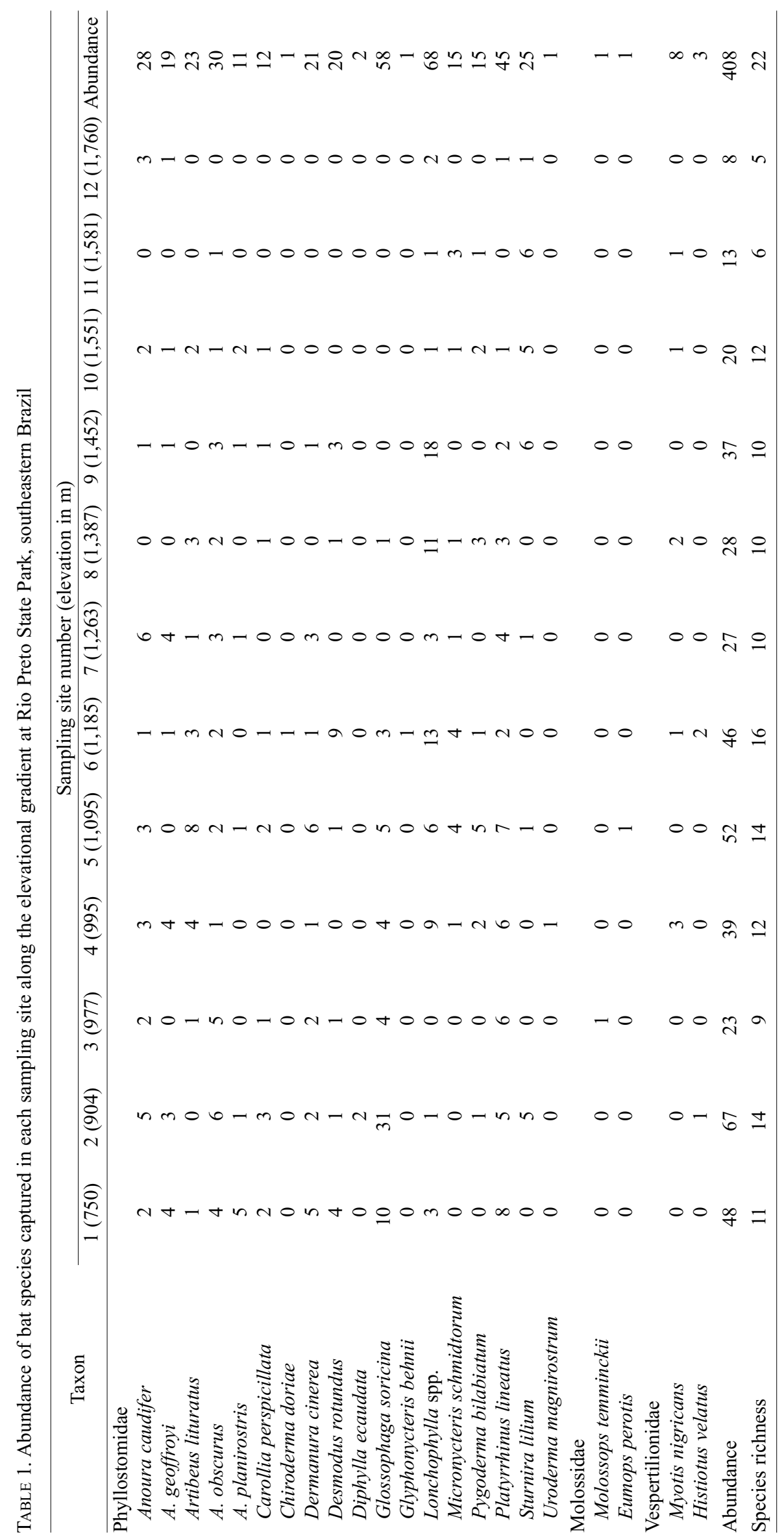


TABLE 2. Summary of bat diversity metrics obtained in 12 sampling sites at Rio Preto State Park, southeastern Brazil

\begin{tabular}{lcccccc}
\hline $\begin{array}{c}\text { Sampling } \\
\text { site ID }\end{array}$ & $\begin{array}{c}\text { Elevation } \\
\text { (m a.s.1.) }\end{array}$ & $\begin{array}{c}\text { Observed species } \\
\text { richness }\end{array}$ & Total abundance & $\begin{array}{c}\text { Rao's quadratic } \\
\text { entropy }\end{array}$ & $\begin{array}{c}\text { Gini-Simpson } \\
\text { index diversity }\end{array}$ & Functional redundancy \\
\hline 1 & 750 & 11 & 48 & 0.62 & 0.87 & 0.25 \\
2 & 904 & 14 & 67 & 0.50 & 0.75 & 0.25 \\
3 & 977 & 9 & 23 & 0.57 & 0.83 & 0.25 \\
4 & 995 & 12 & 39 & 0.62 & 0.87 & 0.24 \\
5 & 1,095 & 14 & 52 & 0.66 & 0.89 & 0.23 \\
6 & 1,185 & 16 & 46 & 0.64 & 0.85 & 0.21 \\
7 & 1,263 & 10 & 27 & 0.60 & 0.86 & 0.25 \\
8 & 1,387 & 10 & 28 & 0.63 & 0.79 & 0.16 \\
9 & 1,452 & 10 & 37 & 0.52 & 0.71 & 0.18 \\
10 & 1,551 & 12 & 20 & 0.61 & 0.88 & 0.26 \\
11 & 1,587 & 6 & 13 & 0.51 & 0.71 & 0.19 \\
12 & 1,760 & 5 & 8 & 0.41 & 0.75 & 0.33 \\
\hline
\end{tabular}

Contrary to our prediction, but still agreeing with our general hypothesis, bat richness and abundance was linearly and inversely correlated to elevation (Fig. 3A-B). The negative slope was much stronger for abundance, as species richness maintained high values overall until around 1,200 m a.s.l. In fact, for species richness it seems to exist some uncertainty on whether the linear or the hump-shaped model has a better fit to our data (Supplementary Fig. S2), although the minimal adequate model approach favours the former. As predicted, variation in functional diversity along the elevational gradient was better explained by the quadratic function (representing the hump-shaped pattern Table 3 and Supplementary Fig. S2). Initially, functional diversity increased with elevation, reaching its maximum value around 1,200 $\mathrm{m}$ a.s.1.; from this elevation upwards the relationship changed and it began to decrease with an increase in elevation (Fig. 3C).

\section{DISCUSSION}

Observed species richness represented $81 \%$ of the species estimated to occur in the study area, indicating that total bat richness at RPSP is likely to reach approximately 30 species. However, the number of species recorded in this study is highly representative; as it corresponds to $69 \%$ of the bats known to occur in the Espinhaço range (Tavares et al., 2008) and almost $20 \%$ of all bat species in the Brazilian Cerrado (Aguiar et al., 2016). Besides the large number of species, bats of conservation concern also occur at RPSP, such as Lonchophylla bokermanni, Histiotus velatus and Glyphonycteris behnii - the last species is included in the Brazilian Red List as Vulnerable (MMA, 2014) and all of them are classified as Data Deficient by IUCN (2015).

Our results show that elevation has a negative effect on important diversity metrics of the bat

TABLE 3. Analyses of variance of the minimal adequate models showing the effect of elevation on species richness, abundance and functional diversity of bats at Rio Preto State Park, southeastern Brazil

\begin{tabular}{|c|c|c|c|c|c|c|}
\hline Response variable & Terms & d.f. & Mean square & $F$-value & $P$-value & $R^{2 *}$ \\
\hline $\begin{array}{l}\text { Richness } \\
(\sim \text { Elevation })\end{array}$ & $\begin{array}{l}\text { Elevation } \\
\text { Residual }\end{array}$ & $\begin{array}{r}1 \\
10\end{array}$ & $\begin{array}{l}38.089 \\
74.161\end{array}$ & 5.14 & 0.047 & 0.33 \\
\hline $\begin{array}{l}\text { Abundance } \\
(\sim \text { Elevation })\end{array}$ & $\begin{array}{l}\text { Elevation } \\
\text { Residual }\end{array}$ & $\begin{array}{r}1 \\
10\end{array}$ & $\begin{array}{l}1919.00 \\
1387.00\end{array}$ & 13.84 & 0.004 & 0.58 \\
\hline $\begin{array}{l}\text { Functional diversity } \\
\left(\sim \text { Elevation+Elevation }^{2}\right)\end{array}$ & $\begin{array}{l}\text { Elevation } \\
\text { Elevation }^{2} \\
\text { Residual }\end{array}$ & $\begin{array}{l}1 \\
1 \\
9\end{array}$ & $\begin{array}{l}0.014 \\
0.020 \\
0.027\end{array}$ & $\begin{array}{l}4.82 \\
6.55\end{array}$ & $\begin{array}{l}0.056 \\
0.031\end{array}$ & 0.55 \\
\hline
\end{tabular}

d.f. - degrees of freedom; $* R^{2}$ — values refer to the minimal adequate model for each parameter investigated. Variables in parentheses are the ones retained in the minimal adequate model 
community at RPSP. A similar effect has been found for large mammals in this same protected area, where species richness and number of records are greater in lower elevations (Pinho et al., 2017). Our models indicate that bat species richness and abundance in the study area decreases linearly as elevation increases. This pattern agrees with some studies
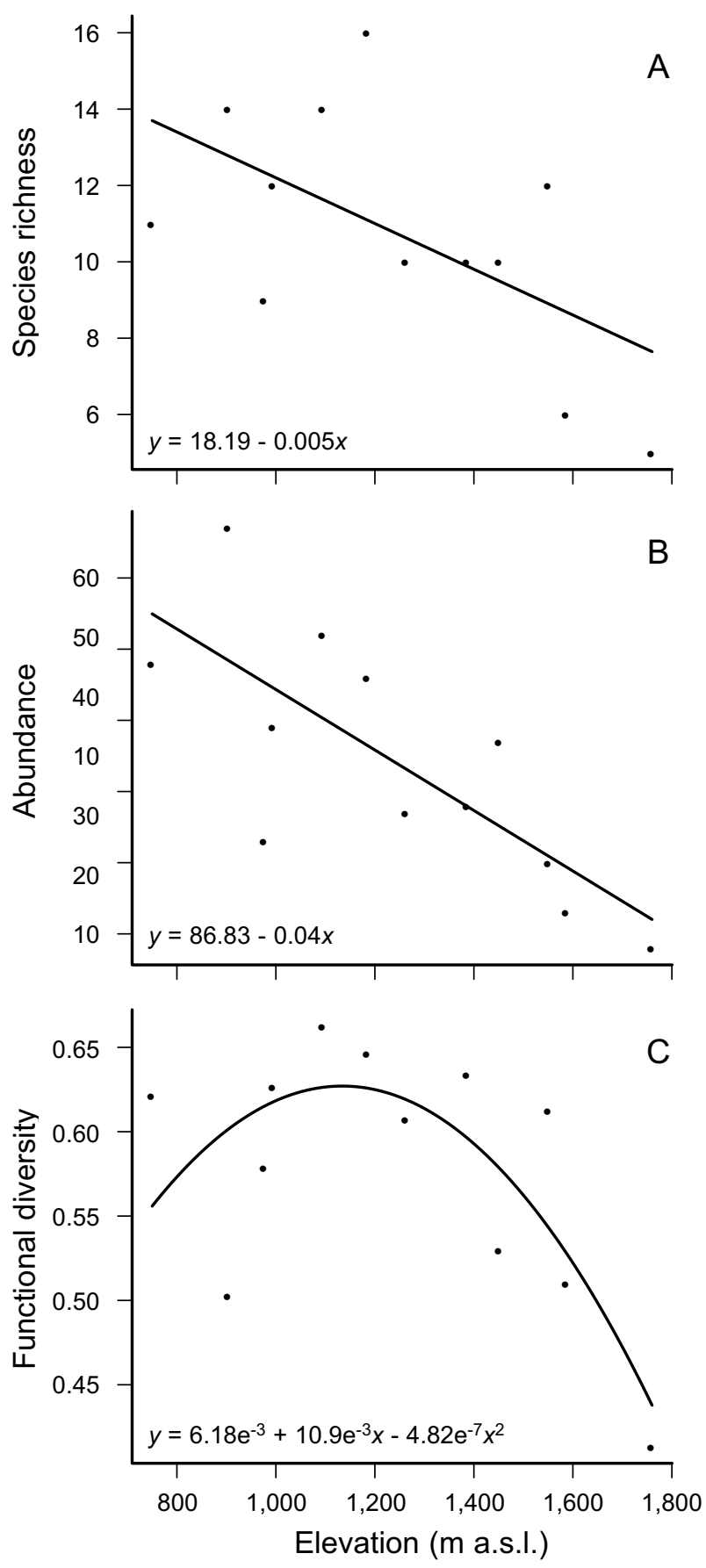

FIG. 3. Effect of elevation on bat species richness (A), abundance (B), and functional diversity (C) at Rio Preto State Park, southeastern Brazil on bats in elevational gradients (e.g., Liden et al., 2014; Martins et al., 2015), but contradicts our predictions of a hump-shaped effect and the results from Bejarano-B. et al. (2007), Piksa et al. (2013) and Stevens (2013). Abundance declined sharply with elevation, but we still found a high number of species in some of the intermediate elevation sites, a possible reason for the uncertainty about which model better explains the relationship between richness and elevation in the study area. An initial plateau in species richness was also observed by Curran et al. (2012) in Malawi, where the number of bat species remained relatively high up to mid-elevations. On the other hand, functional diversity at RPSP peaked in intermediate elevations before decreasing in higher elevations, showing that the hump-shaped pattern may be valid for at least some metrics of the bat community in the Espinhaço.

It is likely that local context will influence the diversity-elevation relationship, with both linear decrease and hump-shaped pattern being possible outcomes in tropical regions. For instance, variation in climate (McCain, 2007a) and anthropogenic pressure (Marini et al., 2011) may cause similar communities to respond in different ways to the elevational gradient. Furthermore, the shape of the relationship is likely to be taxonomic-dependent due to distinct ecological requirements and physiological process among unrelated species. In the Espinhaço range, the effect of elevation on biodiversity has been tested for distinct taxonomic groups, such as mycorrhizal fungi (Coutinho et al., 2015), gall inducing insects (Carneiro et al., 2005, 2009), dung bettles (Nunes et al., 2016) and ants (Costa et al., 2016), and both patterns (hump-shaped and linear) have been observed.

According to Cianciaruso et al. (2009), functional diversity is usually correlated to species richness, as we observed at RPSP, where high values for both metrics were found in the same sampling sites $(r=0.67, t=2.82, d . f .=10, P=0.018)$. The link between them can be partially explained by the low values obtained for functional redundancy, suggesting that bat species captured in our study area have few similar functional traits with little overlap on their role on ecosystem function. If there is little functional overlap among the species recorded, sampling sites with more species are also likely to be the sites with higher functional diversity, due to an additive effect. Because bats can provide several ecosystem services, such as seed dispersal, pollination and control of insect population (Kunz et al., 2011), areas of high bat species richness and, thus, 
high functional diversity, are expected to deliver greater environmental services. Based on our results, at RPSP, we can expect lower and especially intermediate elevations to provide more bat-related environmental benefits than high elevation areas.

Lower diversity in higher elevations is usually explained as a function of lower productivity in these higher areas. Interestingly, NDVI (a surrogate for vegetation productivity - Pettorelli et al., 2005) did not influence abundance nor species richness or functional diversity in our study. In fact, wind speed, relative humidity and temperature (the other variables we thought could affect bats in the study area) also did not have a significant effect on any of the biodiversity metrics we measured. However, there may still be other factors influencing the patterns observed that we did not account for, such as habitat features, resource availability, historic complexity and abiotic variables (other than wind and temperature) - all of which have been previously shown to have an effect on bat diversity along elevational gradients (Graham, 1990; Patterson et al., 1996; Willig et al., 2003; Cowell et al., 2004; McCain, 2007b).

Despite the possible influence of other factors, we show here that elevation has an important effect on the bat community at RPSP. Our findings suggest that natural environments in lower and intermediate elevations $(<1,100 \mathrm{~m}$ a.s.1.) in the Espinhaço mountain range have high biodiversity value for bats. The protection and adequate management of these lower elevation habitats (including natural vegetation outside protected areas) would favour the Espinhaço mammal fauna and complement the conservation efforts focusing on endemic species associated with higher elevation habitats.

\section{ACKNOWLEDGEMENTS}

Funding was provided by CNPq (proc. 563134/2010-0 and 457434/2012-0) through grants to Rede ComCerrado and Instituto Biotrópicos. UFOP (Federal University of Ouro Preto) provided a MSc. scholarship to Eduardo Coelho and CNPq supports Guilherme Ferreira with a PhD scholarship. RPSP manager and staff gave logistic support for field work and IEF-MG provided the research permit. Yuri Bellagamba, Lucas Oliveira, Marco Pacheco, Marcell Pinheiro and Flávia Pezzini helped with bat surveys. Fernando Pinho provided NDVI data for RPSP and produced Fig. 1. Rodrigo Barata made comments in an earlier draft of the manuscript, Fiona Spooner and Daniel Bayley reviewed the final version of this paper.

\section{SUPPLEMENTARY INFORMATION}

Contents: Supplementary Tables S1 and S2: Table S1. Functional traits of bats species surveyed at Rio Preto State Park, southeastern Brazil, used to calculate functional diversity metrics. All data was extracted from literature; Table S2. Comparison of the models to investigate the effect of elevation on the bat community at Rio Preto State Park; Supplementary Figs S1-S3. Fig. S1. Results of residual analysis to assess adequacy of error distribution of the GLM models used to investigate the effect of elevation on bats at Rio Preto State Park; Fig. S2. Occurrence of bats species along the elevational gradient at Rio Preto State Park. Each column represents a sampling site at different elevation (as indicated by the numbers in the bottom); Fig. S3. Effect of elevation on species richness and abundance of frugivorous and nectarivorous bats at Rio Preto State Park. Supplementary Information is available exclusively on BioOne.

\section{LiterATURE Cited}

Aguiar, L. M. S., E. Bernard, V. Ribeiro, R. B. Machado, and G. JONES. 2016. Should I stay or should I go? Climate change effects on the future of Neotropical savannah bats. Global Ecology and Conservation, 5: 22-33.

Barata, I. M., C. M. Correia and G. B. Ferreira. 2016. Amphibian species composition and priorities for regional conservation at the Espinhaço mosaic, Southeastern Brazil. Herpetological Conservation and Biology, 11: 293-303.

Bejarano-Bonilla, D. A., R. Yate, and M. H. Bernal-B. 2007. Diversidad y distribución de la fauna quiroptera en un transecto altitudinal en el departamento del Tolima, Colombia. Caldasia, 2: 297-308.

Bello, F., J. LePš, S. LAVorel, and M. Moretti. 2007. Importance of species abundance for assessment of trait composition: an example based on pollinator communities. Community Ecology, 8: 163-170.

Bernard, E. and M. B. Fenton. 2003. Bat mobility and roosts in a fragmented landscape in Central Amazonia, Brazil. Biotropica, 35: 262-277.

Bianconi, G. V., R. Gregorin, and D. C. Carneiro. 1996. Range extension of the Peale's free-tailed bat Nyctinomops aurispinosus Molossidae) in Brazil. Biota Neotropica, 9: 267-270.

Bordignon, M. O., and A. O. FrançA. 2009. Riqueza, diversidade e variação altitudinal em uma comunidade de morcegos filostomideos (Mammalia: Chiroptera) no centro-oeste do Brasil. Chiroptera Neotropical, 15: 425-433.

BотTA-DuKÁt, Z. 2005. Rao's quadratic entropy as a measure of functional diversity based on multiple traits. Journal of Vegetation Science, 16: 533-540.

Carneiro, M. A. A., G. W. Fernandes, and O. F. F. Souza. 2005. Convergence in the variation of local and regional galling species richness. Neotropical Entomology, 34: 547-553.

Carneiro, M. A. A., R. A. X. Borges, A. P. A. Araújo, and G. W. FERnANDES. 2009. Insetos indutores de galhas da porção sul da Cadeia do Espinhaço, MG. Revista Brasileira de Entomologia, 53: 570-592.

Cianciaruso, M. V., I. A. Silva and M. A. Batalha. 2009. Diversidades filogenética e funcional: novas abordagens para a Ecologia de comunidades. Biota Neotropica, 3: 1-11.

Colwell, R. K. and J. A. Coddington. 1994. Estimating terrestrial biodiversity through extrapolation. Philosophical Transactions of the Royal Society, 345B: 101-118.

Colwell, R. K., C. X. MAO, and J. Chang. 2004. Interpolating, extrapolating, and comparing incidence-based species accumulation curves. Ecology, 85: 2717-2727. 
Costa, F. V., R. Mello, T. C. Lana, and F. S. Neves. 2015. Ant fauna in megadiverse mountains: a checklist for the rocky grasslands. Sociobiology, 62: 228-245.

Coutinho, E. S., G. W. Fernandes, R. L. Berbara, H. M. VALÉRIO, and B. T. Goto. 2015. Variation of arbuscular mycorrhizal fungal communities along an altitudinal gradient in rupestrian grasslands in Brazil. Mycorrhiza, 25: 627-638.

Crawley, M. J. 2012. The R Book, 2nd edition. John Wiley \& Sons. Chichester, $1051 \mathrm{pp}$.

Curran, M., M. Kopp, J. Beck, and J. Fahr. 2012. Species diversity of bats along an altitudinal gradient on Mount Mulanje, southern Malawi. Journal of Tropical Ecology, 28: 243-253.

Debastiani, V. J., and V. D. Pillar. 2012. SYNCSA - R tool for analysis of metacommunities based on functional traits and phylogeny of the community components. Bioinformatics, 28: 2067-2068.

Dehling, D. M., T. Töpfer, H. M. Schaefer, P. Jordano, K. BöHNING-GAESE, and M. SchleunING. 2014. Functional relationships beyond species richness patterns: trait matching in plant-bird mutualisms across scales. Global Ecology and Biogeography, 23: 1085-1093.

Dias, D., and A. L. Peracchi. 2008. Bats from Tinguá Biological Reserve, Rio de Janeiro state, southeastern Brazil (Mammalia: Chiroptera). Revista Brasileira de Zoologia, 25: 333-369.

Díaz, S., J. Fargione, C. F. Stuart III, and D. Tilman. 2006. Biodiversity loss threatens human well-being. PLoS Biology, 4: e277.

EISENBERG, J. F., and K. H. RedFord. 1999. Mammals of Neotropics, Volume 3: Ecuador, Bolivia, Brazil. The University of Chicago Press, Chicago, 609 pp.

EMmons, L. H., and F. FeER. 1997. Neotropical rainforest mammals: a field guide, 2nd edition. University of Chicago Press, Chicago, 318 pp.

Esbérard, C. E. L. 2004. Morcegos no Estado do Rio de Janeiro. Ph.D. Thesis, Universidade do Estado do Rio de Janeiro, Rio de Janeiro, $238 \mathrm{pp}$.

Eterovick, P. C., A. C. O. Q. Carnaval, D. M. Borgesnojosa, D. L. Silvano, M. V. Segalla and I. Sazima. 2005. Amphibian declines in Brazil: an overview. Biotropica, 37: 166-179.

Ferreira, L. G., H. Yoshioka, A. Huete, and E. E. SANo. 2003. Seasonal landscape and spectral vegetation index dynamics in the Brazilian Cerrado: an analysis within the large-scale biosphere-atmosphere experiment in Amazônia (LBA). Remote Sensing of Environment, 87: 534-550.

GanNon, M. R., M. R. Willig, and J. K. Jones, JR. 1989. Sturnira lilium. Mammalian Species, 333: 1-5.

GARDNER, A. F. 2008. Order Chiroptera. Pp. 187-580, in Mammals of South America. Volume 1: Marsupials, xernarthrans, shrews and bats (A. F. GARDNER, ed.). University of Chicago Press, Chicago, Illinois, $\mathrm{xx}+669$ pp.

Geraldes, M. P. 1999. Aspectos ecológicos da estruturação de um conjunto taxionômico de morcegos na região de Ariri (Cananéia, SP). M.Sci. Thesis, Universidade de São Paulo, São Paulo, 128 pp.

Goodman, S. M., A. Andrianarimisa, L. E. Olson, and V. Sorimalala. 1996. Patterns of elevational distribution of birds and small mammals in the humid forests of Montagne D'Ambre, Madagascar. Ecotropica, 2: 87-98.

GraHAM, G. L. 1983. Changes in bat species diversity along an elevational gradient up Peruvian Andes. Journal of Mammalogy, 64: 559-571.
GrahaM, G. L. 1990. Bats versus birds: comparisons among Peruvian vertebrate faunas along an elevational gradient. Journal of Biogeography, 17: 657-668.

HeAney, L. R. 2001. Small mammal diversity along elevational gradients in the Philippines: an assessment of patterns and hypotheses. Global Ecology and Biogeography, 10: $15-39$.

Heaney, L. R., P. D. Heideman, E. A. Rickart, R. B. Utzurrum and J. S. H. KLOMPEN. 1989. Elevational zonation of mammals in the central Philippines. Journal of Tropical Ecology, 5: 259-280.

Hopper, S. D., F. A. O., Silveira, and P. L. Fiedler. 2016. Biodiversity hotspots and Ocbil theory. Plant and Soil, 403: 167-216.

Horner, M. A., T. H. Fleming, and C. T. SAhey. 1998. Foraging behaviour and energetics of a nectar-feeding bat, Leptonycteris curasoae (Chiroptera: Phyllostomidae). Journal of Zoology (London), 244: 575-586.

IEF-MG. 2004. Plano de manejo do Parque Estadual do Rio Preto. IEF-MG, Belo Horizonte, 217 pp.

IUCN. 2015. The IUCN Red List of Threatened Species. www. iucnredlist.org. Visited on 03 June 2016.

JABERG, C. and A. GUISAN. 2001. Modelling the distribution of bats in relation to landscape structure in a temperate mountain environment. Journal of Applied Ecology, 38: 1169-1181.

Juste, B. J., and J. PÉrez Del VAL. 1995. Altitudinal variation in the subcanopy fruit bat guild in Bioko Island, Equatorial Guinea, Central Africa. Journal of Tropical Ecology, 11: 141-146.

KAÑUCH, P. and A. KRISTín, 2006. Altitudinal distribution of bats in the Polàna Mts area (Central Slovakia). Biologia, 61: 605-610.

KÖRNER, C. 2000. Biosphere responses to $\mathrm{CO}^{2}$ enrichment. Ecological Applications, 10: 1590-1619.

Kunz, T. H., E. B. De Torrez, D. Bauer, T. Lobova, and T. H. FLEMING. 2011. Ecosystem services provided by bats. Annals of the New York Academy of Sciences, 1223: 1-38.

Linden, V. M. G., S. M. Weier, I. Gaigher, H. J. Kuipers, M. J. A. Weterings, and P. J. TAYLOR. 2014. Changes of bat activity, species richness, diversity and community composition over an altitudinal gradient in the Soutpansberg Range, South Africa. Acta Chiropterologica, 16: 27-40.

Loreau, M. 2004. Does functional redundancy exist? Oikos, 104: 606-611.

Marini, L., E. Bona, W. E. Kunin, and K. J. Gaston. 2011. Exploring anthropogenic and natural processes shaping fern species richness along elevational gradients. Journal of Biogeography, 38: 78-88.

Martins, M. A., W. D. Carvalho, D. Dias, D. S. França, M. B. Oliveira, and A. L. Peracchi. 2015. Bat species richness (Mammalia, Chiroptera) along an elevational gradient in the Atlantic Forest of Southeastern Brazil. Acta Chiropterologica, 17: 401-409.

McCAIN, C. M. 2007a. Area and mammalian elevational diversity. Ecology, 88: 76-86.

MCCAIN, C. M. 2007b. Could temperature and water availability drive elevational diversity? A global case study for bats. Global Ecology and Biogeography, 16: 1-13.

Meyer, W. M., K. A. Hayes, and A. L. Meyer. 2008. Giant African snail, Achatina fulica, as a snail predator. American Malacological Bulletin, 24: 117-119.

MMA [Ministério do Meio Ambiente]. 2014. Lista das espécies de fauna ameaçadas de extinção. Available at http://www. 
icmbio.gov.br/portal/biodiversidade/fauna-brasileira/listade-especies.htm.

Moras, L. M., L. F. O. Bernardi, G. Graciolli, and R. GreGORIN. 2013. Bat flies (Diptera: Streblidae, Nycteribiidae) and mites (Acari) associated with bats (Mammalia: Chiroptera) in a high-altitude region in southern Minas Gerais, Brazil. Acta Parasitologica, 58: 556-563.

Norberg, U. M. 1998. Morphological adaptations for flight in bats. Pp. 93-108, in Bat biology and conservation (T. H. KUNZ and P. A. RACEY, eds.). Smithsonian Institution Press, Washington, D.C., xiv $+365 \mathrm{pp}$.

Norberg, U. M., and J. M. V. RAYNer. 1987. Ecological morphology and flight in bats (Mammalia, Chiroptera): wing adaptations, flight performance, foraging strategy and echolocation. Philosophical transactions of the Royal Society, 1179B: 335-427.

Nunes, C. A., R. F. Braga, J. E. C. Figueira, F. S. Neves, and G. W. FERNANDES. 2016. Dung beetles along a tropical altitudinal gradient: environmental filtering on taxonomic and functional diversity. PLoS ONE, 11: e0157442.

Oksanen, J., F. G. Blanchet, M. Friendly, R. Kindt, P. LeGENDRE, D. McGlinN, P. R. Minchin, R. B. O'HaRA, G. L. SimPSON, P. SolYMOS, et al. 2016. vegan: community ecology package. R package version 2.4-0. Available at https:// CRAN.R-project.org/package= $=$ vegan.

PALMER, M. 1990. The estimation of species richness by extrapolation. Ecology, 71: 1195-1198.

PAtTerson, B. D., V. PACheCO, and S. Solari. 1996. Distribution of bats along an elevational gradient in the Andes of southeastern Peru. Journal of Zoology (London), 240: 637-658.

Patterson, B. D., D. F. Stotz, S. Solari, J. W. Fitzpatrick, and V. PACHECO. 1998. Contrasting patterns of elevational zonation for birds and mammals in the Andes of southeastern Peru. Journal of Biogeography, 25: 593-607.

Pettorelli, N., J. O. ViK, J. Gaillard, C. Tucker, and N. C. STENSETH. 2005. Using the satellite derived NDVI to assess ecological responses to environmental change. Trends in Ecology \& Evolution, 20: 503-510.

PIKSA, K., J. NowAK, M. ŻMIHORSKI, and W. BogdANOwicz. 2013. Nonlinear distribution pattern of hibernating bats in caves along an elevational gradient in mountain (Carpathians, Southern Poland). PLoS ONE, 8: e68066.

Pinho, F. F., G. B. Ferreira, and A. P. Paglia. 2017. Influence of vegetation physiognomy, elevation and fire frequency on medium and large mammals in two protected areas of the Espinhaço Range. Zoologia, 34: e11921.

R CORE TEAm. 2016. R: a language and environment for statistical computing. R Foundation for Statistical Computing, Vienna, Austria. Available at https://www.R-project.org/.

RAHBEK, C. 1995. The elevational gradient of species richness a uniform pattern. Ecography, 18: 200-205.

RAHBEK, C. 2005. The role of spatial scale and the perception of large-scale species-richness patterns. Ecology Letters, 224-239.

RAO, C. R. 1982. Diversity and dissimilarity coefficients: a unified approach. Theoretical Population Biology, 21: 24-43.

Rapini, A., P. L. Ribeiro, S. Lambert, and J. R. Pirani. 2008. A flora dos campos rupestres da Cadeia do Espinhaço. Megadiversidade, 4: 16-24.
Reis, N. R., M. N. Fregonezi, A. L. Peracchi, and O. A. ShIBATTA. 2013. Morcegos do Brasil: guia de campo. Technical Books, Rio de Janeiro, $252 \mathrm{pp}$.

Rodrigues, M. T. 2005. The conservation of Brazilian reptiles: challenges for a megadiverse country. Conservation Biology, 19: 659-664.

SANDERS, N., and C. RAHBEK. 2012. The patterns and causes of elevational diversity gradients. Ecography, 35: 1-3.

Silveira, F. A., D. Negreiros, N. P. Barbosa, E. Buisson, F. F. Carmo, D. W. Carstensen, A. A. Conceição, T. G. CorNELISSEN, L. EChternacht, G. W. Fernandes, et al. 2015. Ecology and evolution of plant diversity in the endangered campo rupestre: a neglected conservation priority. Plant and Soil, 403: 129-152.

Stevens, G. C. 1992. The elevational gradient in altitudinal range: an extension of rapoport's latitudinal rule to altitude. American Naturalist, 140: 893-911.

Stevens, R. D. 2013. Gradients of bat diversity in Atlantic forest of South America: environmental seasonality, sampling effort and spatial autocorrelation. Biotropica, 45: 764-770.

Stevens, R. D., S. B. Cox, R. E. Strauss, and M. R. Willig. 2003. Patterns of functional diversity across an extensive environmental gradient: vertebrate consumers, hidden treatments and latitudinal trends. Ecology Letters, 6: 1099-1108.

Tavares, V. C., R. Gregorin, and A. L. Peracchi. 2008. Diversidade de morcegos no Brasil: lista atualizada com comentários sobre distribuição e taxonomia. Pp. 25-58, in Morcegos no Brasil: biologia, sistemática, ecologia e conservação (S. M. Pacheco, R. V. Marques, and C. E. L. Esberard). Armazem Digital Comunicaçao Ltda, Porto Alegre, RS, 574 pp.

TILman, D. 2001. Functional diversity. Pp. 109-120, in Encyclopedia of biodiversity (LEVIN, S. A.). Academic Press, San Diego, C.A., 870 pp.

VASCONCELOS, M. F., and T. A. Melo, JR. 2001. An ornithological survey of Serra do Caraça, Minas Gerais, Brazil. Cotinga, 15: 21-31.

VITTA, F. A. 2002. Diversidade e conservação da flora nos campos rupestres da Cadeia do Espinhaço em Minas Gerais. Pp. 90-94, in Biodiversidade, conservação e uso sustentável da flora do Brasil (E. L. AraúJo, A. N. Moura, E. S. B. SAMPAIO, L. M. S. GESTINARI, and J. M. T. CARNEIRo, eds.). Universidade Federal Rural de Pernambuco/Sociedade Botânica do Brasil, Imprensa Universitária, Recife, PE, 262 pp.

Walther, B. A., and J. L. Moore. 2005. The concepts of bias, precision and accuracy, and their use in testing the performance of species richness estimators, with a literature review of estimator performance. Ecography, 28: 815-829.

Williams, S. E., L. P. Shoo, R. Henriod, and R. G. Pearson. 2012. Elevational gradients in species abundance, assemblage structure and energy use of rainforest birds in the Australian Wet Tropics Bioregion. Austral Ecology, 35: 650-664.

Willig, M. R., D. M. Kaufman, and R. D. Stevens. 2003. Latitudinal gradients of biodiversity: pattern, process, scale, and synthesis. Annual Review of Ecology and Systematics, 34: $273-309$.

Received 04 October 2016, accepted 10 August 2017 